Marquette University

e-Publications@Marquette

$1-1-2014$

\title{
The Interaction Between FDI and Infrastructure Capital in The Development Process
}

Farrokh Nourzad

Marquette University, farrokh.nourzad@marquette.edu

David N. Greenwold

Associated Bank

Rui Yang

Marquette University

Accepted version. International Advances in Economic Research, Vol. 20, No. 2 (January 2014), 203-212. DOI. (C) 2014 International Atlantic Economic Society. Used with permission.

Shareable Link. Provided by the Springer Nature SharedIt content-sharing initiative. 


\title{
The Interaction Between FDI and Infrastructure Capital in The Development Process
}

\author{
Farrokh Nourzad \\ Economics Department, Marquette University, \\ Milwaukee, WI \\ David N. Greenwold \\ Associated Bank \\ Milwaukee, WI \\ Rui Yang \\ Economics Department, Marquette University, \\ Milwaukee, WI
}

\begin{abstract}
This paper focuses on the possible interaction between foreign direct investment (FDI) and the host country's infrastructure base. Its central hypothesis is that the effect of FDI on per capita real income depends, at least in part, on the size of the recipient country's infrastructure. This hypothesis is tested in a panel of 46 countries and 5-year averages over the 1980-2000 period using the size of three types of infrastructure capital: telecommunication, power generation, and network of roads or highways. The
\end{abstract}


NOT THE PUBLISHED VERSION; this is the author's final, peer-reviewed manuscript. The published version may be accessed by following the link in the citation at the bottom of the page.

results indicate that the size of the host country's infrastructure base helps to improve the marginal effect of FDI on real income.

Keywords: FDI Infrastructure capital Economic development

\section{Introduction}

Liberalization of international trade and globalization of commerce and finance since the early 1970s has led to the emergence of a large body of literature that is concerned with the effect of various open-economy factors on economic growth and development. One such factor has been foreign direct investment (FDI), which has been the subject of many theoretical and empirical studies (Aitken and Harrison 1989; Bengoa-Calvo and Sanchez-Robels 2003; Blomstrom et al. 1992; Borensztein et al. 1998; Damijan et al. 2003; Lipsey 2002; Kohpaiboon 2002; Nourzad 2008). The general consensus appears to be that FDI contributes to the standard of living through several channels such as technology transfer.

An issue that has received a lot of attention is the interaction in the process of economic growth and development between FDI and several macroeconomic factors including human capital (Borensztein et al. 1998; Ciruelos and Wang 2005; Figlio and Blonigen 2000; Urata and Kawai 2000; Xu 2000), financial development (Alfaro et al. 2004, 2006; Choong et al. 2004; Dutta and Roy 2008; Hermes and Lensink 2003; Maswana 2008), and openness (Balasubramanyam et al. 1996; Kohpaiboon 2002; Nourzad 2008). The present paper is concerned with the interaction between FDI and the host country's infrastructure base. We argue that the effect of FDI on real income per capita may depend, at least in part, on the infrastructure base of the recipient country's infrastructure. Increased infrastructure capital has been found to increase investment in domestic private capital (Turnovsky 1996; Ram 1986; Grossman 1988; Bairam and Ward 1993; Buiter 1977; Eberts 1986).

Turnovsky (1996) uses a one-sector endogenous growth model of a closed economy in which tax-financed public expenditures affect the productivity of the existing stock of capital in two ways. First, public expenditures directly enhance the productivity of private capital by improving production conditions. Second, these expenditures "also 
reduce the costs associated with investment and thereby facilitate the accumulation of the flow of new [private] capital." Taken together, these two effects imply that higher public expenditures increase the marginal efficiency of private capital. We contend that the same complementarity should also hold for FDI.

We examine the interaction between FDI and infrastructure capital in a panel of 46 countries and 5-year averages over the 19802000 period using the size of three types of infrastructure capital: telecommunication, power generation, and roads/highways. Our findings indicate that in general the size of the host country's infrastructure base help to improve the marginal effect of FDI on real income.

The remainder of the paper is organized as follows. The next section offers a review of the existing literature on the effects of FDI and infrastructure capital on growth and development. This is followed by a section in which we introduce our synthesis in terms of the interaction between FDI and infrastructure capital in the process of economic development. Next, we describe our empirical model and the data used in this study followed by a section that reports the results. The paper concludes with a summary of this study along with a few suggestions for further research in this area.

\section{Previous Work}

An issue of great concern to policymakers, international organizations, and economists is the potential effect of FDI on economic growth and standard of living. The general consensus appears to be that FDI contributes to economic growth through several channels, the most important of which is arguably technology transfer. Romer (1986) recognized that "knowledge spillovers" may be an unintended consequence of decisions to invest in competitive markets. These spillovers, Romer argues, increase knowledge in proportion to the physical stock of capital, which results in the aggregate production function not exhibiting decreasing returns. This aspect of the endogenous growth theory was soon altered to allow firms to invest in research and development so as to gain monopolistic power (Romer 1987). Grossman and Helpmann (1991) show that knowledge spillovers are not limited to domestic investment, as international

International Advances in Economic Research, Vol 20, No. 2 (May 2014): pg. 203-212. DOI. This article is @ International Atlantic Economic Society and permission has been granted for this version to appear in e-Publications@Marquette. International Atlantic Economic Society does not grant permission for this article to be further copied/distributed or hosted elsewhere without the express permission from International Atlantic Economic Society. 
trade can also familiarize a country with certain technologies that did not previously exist in that country. The existence of multinational corporations thus allows for technologies to be shared between countries via the learning-by-doing process, which can be transferred to other countries through FDI.

Borensztein et al. (1998) test the effect of FDI on economic growth using a panel of 69 industrial and developing countries from 1978 to 1998 . Their results indicate that FDI is a principal vehicle for the transfer of technology, contributing more to economic growth than domestic investment. However, the productivity effect of FDI is sustained only when the host country has a minimum threshold stock of human capital. In fact, for countries with very low levels of human capital, the direct effect of FDI on economic growth is negative. Blomstrom et al. (1992) use a sample of rich and poor countries and find that inflow of FDI exerts a significant growth effect in high-income countries but not in low-income countries. Not coincidentally, lowincome countries also have a much lower stock of human capital. Ciruelos and Wang (2005) analyze data for 57 countries from 1988 to 2001 and find that FDI and economic growth are positively correlated. They also find that FDI serves as an important channel of international technology diffusion. However, as with Borensztein et al., they find that for inward FDI to promote economic welfare and technology diffusion, a certain level of human capital has to be reached by the host country.

Urata and Kawai (2000) find that human capital, as measured by secondary school enrollment, is positively related to the FDI effect on the economy as well as to intra-firm technology transfers from Japan to other Asian countries. Xu (2000) finds that U.S. multinational firms have a positive impact on growth in total factor productivity when the host country meets a minimum human capital threshold. Figlio and Blonigen (2000) study the impact of FDI on South Carolina economy and find that wages are seven times higher in cities that contain foreign firms compared to cities with only domestic firms. Again, a qualification to this result is that the work force must have a specific level of human capital.

Not all studies find a positive correlation between FDI, human capital, and growth. Aitken and Harrison (1989) use a panel data set 
to study technology spillovers from foreign firms to domestic firms in Venezuela from 1976 to 1989 . They find that the net impact of foreign investment is "quite small" and that any gain from foreign investment appears to be entirely captured by joint ventures. The authors hypothesize that the productive advantage of foreign ownership would increase the stock of human capital if domestic workers absorb the technological spillover through training and learning-by-doing activities. Krogstrup and Matar (2005) study possible reasons for some Middle Eastern countries failing to attract FDI relative to other countries since the early 1990s. They consider FDI and growth through absorptive capacity and conclude that there is no correlation between FDI and growth and that there is no a priori reason for Middle Eastern countries to attract FDI inflows because the absorptive capacity is insufficient in these countries. The authors declare that an upgrade of the human capital stock through improvements in the quality and quantity of education would enrich absorptive capacities and allow FDI to potentially improve overall economic welfare.

In addition to the literature on the interaction between FDI and human capital in the process of growth and development, a large body of published work also exists that is concerned chiefly with the linkage between FDI and financial development. Modern growth theory identifies two specific channels through which the financial sector can affect long-run growth. One channel is through the impact of the financial sector on capital accumulation and another is through its impact on the rate of technological progress. These effects arise from the intermediation function of the financial sector that facilitates and encourages inflows of foreign capital. Much of this literature investigates the development of the domestic financial sector in transferring the technological diffusion embodied in FDI inflows. Alfaro et al. (2004) examine the relationship among foreign direct investment, financial markets, and economic growth. They explore whether countries with a more developed financial system gain additional benefits from FDI. Based on data for 71 countries from 1975 to 1995 , their empirical results show that although FDI alone plays an "ambiguous" role in contributing to economic growth, a well-developed financial market enables the country to benefit from FDI. This is consistent with the findings by Hermes and Lensink (2003), Choong et al. (2004), and Alfaro et al. (2006). 


\section{The Interaction Between FDI and Infrastructure Capital}

Our review of the literature on growth and development effects of FDI indicate that to date no work has been done regarding whether improvements in the size of an economy's infrastructure base enhances the positive effect of FDI on growth and development. However, there exist two strands of research concerning the relationship between FDI and the infrastructure base of the host economy in the literature. One line of research examines the effect of inflow of FDI on the infrastructure base of the receiving country. Yamin and Sinkovics (2009, P. 153) postulate that "FDI diverts resources from public investment in infrastructure and thus constrains basic infrastructure development." This is supported by the work of Zhuang (2011) who uses an annual panel of 50 states and Washington, DC and finds that FDI has a negative effect on state highway expenditure per capita. Kirkpatrick et al. (2006) empirically examine the effects of FDI on infrastructure in middle and lower income developing countries during the period 1990 to 2002 with special emphasis on the role of quality of the regulatory framework. They find that existence of an effective regulatory framework increases FDI in infrastructure.

The second strand of research pertains to the effect of infrastructure capital on the inflow of FDI. Using annual data for Malaysia for the period from 1960 to 2005, Ang (2008) finds that expansion of the infrastructure base measured in terms of government expenditure on transportation and communication increases the inflow of FDI into the host country. Using a cross-sectional sample of 71 developing countries and the number of telephones per 1,000 inhabitants as a measure of infrastructure development, Asiedu (2002) finds that, while a better infrastructure increases the flow of FDI to non-Sub-Saharan African countries, it has no significant impact on the inflow to Sub-Saharan economies. Using a cross-sectional sample of 293 foreign firms that invested in Turkey in 1995, Deichmann et al. (2003) find no evidence that public investment in infrastructure capital attracts foreign multinational firms to locate in Turkey. Other studies of the effect of infrastructure on FDI include those by Wheeler and Mody (1992) and Kumar (1994).

International Advances in Economic Research, Vol 20, No. 2 (May 2014): pg. 203-212. DOI. This article is C International Atlantic Economic Society and permission has been granted for this version to appear in e-Publications@Marquette. International Atlantic Economic Society does not grant permission for this article to be further copied/distributed or hosted elsewhere without the express permission from International Atlantic Economic Society. 
The general finding of the studies cited above is that increased infrastructure capital may lead to increased inflow of FDI. This parallels the findings in the infrastructure-domestic investment literature that there is a positive effect from infrastructure to domestic private investment (Turnovsky 1996; Ram 1986; Grossman 1988; Bairam and Ward 1993; Buiter 1977, and Eberts 1986). We take the issue one step further by arguing that increased size of an economy's infrastructure base increases the effect of FDI on growth and development above and beyond the direct effect of FDI alone. This enhancement in the overall effect of FDI on standard of living is not so much a result of increased inflow of FDI. Rather it is due to the increased efficiency with which FDI is utilized in the production and distribution processes. As far as we know, thus far this issue has not been investigated.

In order to examine the potential interaction between FDI and infrastructure capital, we begin by extending the augmented Solow model due to Mankiw et al. (1992) to include lagged per capita real GDP to capture the dynamics of the relationship between per capita real GDP and its determinants as well as FDI and its interaction with infrastructure capital. Thus we express the logarithm of per capita real income $(Y)$ as a function of the logarithm of the saving rate $(S R)$, the logarithm of human capital $(H C)$, population growth rate $(P O P G)$, oneperiod lagged value of per capita real GDP $\left(Y_{i t-1}\right)$, the logarithm of the stock of foreign direct investment (FDI) and a random error term $\left(e_{i t}\right)$ where $i$ is the country index and $t$ is the time index:

\section{$\ln Y_{i t}=\alpha_{0}+\alpha_{1} \ln S R_{i t}+\alpha_{2} H C_{i t}+\alpha_{3} P O P G_{i t}+\alpha_{4} \ln Y_{i t}-1+\alpha_{5} \mathrm{l}$ $\mathrm{n} F D I_{i t}+e_{i t}$}

We hypothesize that the effect of FDI on per capita real income, that is the parameter $a_{5}$ in the above equation, is not constant but it depends on the stock of infrastructure capital (IK) of the host country:

$\alpha_{5}=\beta_{1}+\beta_{2} \ln I K_{i t}$

International Advances in Economic Research, Vol 20, No. 2 (May 2014): pg. 203-212. DOI. This article is @ International Atlantic Economic Society and permission has been granted for this version to appear in e-Publications@Marquette. International Atlantic Economic Society does not grant permission for this article to be further copied/distributed or hosted elsewhere without the express permission from International Atlantic Economic Society. 
Substituting Eq. (2) into (1) and collecting terms yields:

\section{$\ln Y_{i t}=\alpha_{0}+\alpha_{1} \ln S R_{i t}+\alpha_{2} H C_{i t}+\alpha_{3} P O P G_{i t}+\alpha_{4} \ln Y_{i t}-1+\beta_{1} 1$ $\mathrm{n} F D I_{i t}+\beta_{2}\left(\ln F D I_{i t} \times \ln I K_{i t}\right)+e_{i t}$}

The parameter of interest is $\beta_{2}$, the coefficient on the interaction term. A positive and statistically significant $\beta_{2}$ would suggest that increases in the infrastructure base of the host country would increase the impact of FDI on real income.

\section{Data}

We estimate Eq. (3) using a panel of 46 countries and 5-year averages of the variables over the $1980-2000$ period. ${ }^{1}$ We quantify the variables entering Eq. (3) as follows. For income, we use per capita real GDP based on purchasing power parity (PPP) in 2005 international dollars. For the saving rate we use the ratio of gross domestic saving to GDP. The growth rate of population over the age of 25 is used for POPG. Our measure of human capital is years of secondary school completed by population age 25 and older. For FDI, we use the stock of inward FDI as a percentage of GDP from the UN Conference on Trade and Development.

We use three alternative measures of the stock of infrastructure capital. The first, which relates to transportation infrastructure, is the length of road networks, in kilometers per square kilometer of land area (IK1). Our second measure relates to the economy's powergenerating infrastructure and is expressed as mega-watts of electricity per 1,000 workers (IK2). The final measure, which represents the telecommunication infrastructure, is the number of main telephone lines per 1,000 workers (IK3).

\section{Results}

Our estimation strategy is as follows. First, we estimate a base model that includes the primary determinants of per capita real income: the saving rate, human capital, population growth, and FDI. 
Next, we add to this model a new variable that is the product of FDI and an index of the aggregate stock of infrastructure capital of the host country $(P C I K)$, which we construct following Calderón and Servén (2004) using the first principal component of the three infrastructure stock variables. ${ }^{2}$ Next, we replace $P C I K$ alternatively with the individual infrastructure series (transportation, power generation, and telecommunication).

We specify all panel regression equations as cross-sectional random-effect models and estimate them using the Generalized Method of Moments (GMM). ${ }^{3}$ In all equations, we use the lagged values of the dependent and independent variables as instruments, and use the Sargan J-statistic to test the null hypothesis of overidentifying moment conditions to ensure that the instruments are not correlated with the error term.

Estimation results for the base model as well as regression equations that include the interaction of FDI with each of the three infrastructure capital stock variables are reported in Table 1 . The results in column 1 pertaining to the base model meet our a priori expectations. The estimated coefficient on the saving rate is positive and statistically significant at the $1 \%$ level. The point estimate associated with the human capital variable is also positive and significant at the $5 \%$ level. The estimated effect of population growth is negative as expected and is statistically significant albeit at the $0.133 / 2=6.65 \%$ level of a one-tailed test. The one-period lagged value of per capita real GDP exerts a statistically significant positive effect on the current period's per capita real GDP. The estimated coefficient associated with FDI is also positive and significant at the $1 \%$ level

Table 1. Panel GMM EGLS random effect estimates of the logarithm of per capita real GDP 5-year averages for 1980-1984, 1985-1989, 1990-1994, 1995-1999 (two-tailed $P$-values based on White's cross-sectional standard errors in parentheses)

\begin{tabular}{llllll} 
& \multicolumn{1}{c}{$\mathbf{1}$} & \multicolumn{1}{c}{$\mathbf{2}$} & \multicolumn{1}{c}{$\mathbf{3}$} & \multicolumn{1}{c}{$\mathbf{4}$} & \multicolumn{1}{c}{$\mathbf{5}$} \\
Constant & 0.518 & 0.571 & 0.514 & 0.581 & 0.593 \\
& $(0.178)$ & $(0.112)$ & $(0.180)$ & $(0.086)^{\mathrm{c}}$ & $(0.062)^{\mathrm{c}}$ \\
$\ln (\mathrm{SR})$ & 0.065 & 0.067 & 0.066 & 0.068 & 0.064 \\
& $(0.000)^{\mathrm{a}}$ & $(0.003)^{\mathrm{a}}$ & $(0.000)^{\mathrm{a}}$ & $(0.002)^{\mathrm{a}}$ & $(0.003)^{\mathrm{a}}$ \\
$\ln (\mathrm{HC})$ & 0.013 & 0.011 & 0.013 & 0.008 & 0.012 \\
& $(0.015)^{\mathrm{b}}$ & $(0.000)^{\mathrm{a}}$ & $(0.000)^{\mathrm{a}}$ & $(0.000)^{\mathrm{a}}$ & $(0.000)^{\mathrm{a}}$
\end{tabular}

International Advances in Economic Research, Vol 20, No. 2 (May 2014): pg. 203-212. DOI. This article is @ International Atlantic Economic Society and permission has been granted for this version to appear in e-Publications@Marquette. International Atlantic Economic Society does not grant permission for this article to be further copied/distributed or hosted elsewhere without the express permission from International Atlantic Economic Society. 
NOT THE PUBLISHED VERSION; this is the author's final, peer-reviewed manuscript. The published version may be accessed by following the link in the citation at the bottom of the page.

\begin{tabular}{|c|c|c|c|c|c|}
\hline & 1 & 2 & 3 & 4 & 5 \\
\hline POPG & $\begin{array}{l}-0.070 \\
(0.133)\end{array}$ & $\begin{array}{l}-0.066 \\
(0.148)\end{array}$ & $\begin{array}{l}-0.068 \\
(0.114)\end{array}$ & $\begin{array}{l}-0.070 \\
(0.124)\end{array}$ & $\begin{array}{l}-0.066 \\
(0.153)^{a}\end{array}$ \\
\hline $\ln (\operatorname{RGDP}(-1))$ & $\begin{array}{l}0.931 \\
(0.000)^{a}\end{array}$ & $\begin{array}{l}0.924 \\
(0.000)^{a}\end{array}$ & $\begin{array}{l}0.930 \\
(0.000)^{a}\end{array}$ & $\begin{array}{l}0.924 \\
(0.000)^{a}\end{array}$ & $\begin{array}{l}0.923 \\
(0.000)^{a}\end{array}$ \\
\hline $\ln (F D I)$ & $\begin{array}{l}0.024 \\
(0.000)^{a}\end{array}$ & $\begin{array}{l}0.015 \\
(0.077)^{c}\end{array}$ & $\begin{array}{l}0.025 \\
(0.000)^{a}\end{array}$ & $\begin{array}{l}0.023 \\
(0.000)^{a}\end{array}$ & $\begin{array}{l}-0.0 .002 \\
(0.933)\end{array}$ \\
\hline $\ln (\mathrm{FDI}) *$ PCIK & & $\begin{array}{l}0.003 \\
(0.003)^{a}\end{array}$ & & & \\
\hline $\ln (\mathrm{FDI}) * \ln (\mathrm{IK} 1)$ & & & $\begin{array}{l}0.001 \\
(0.537)\end{array}$ & & \\
\hline $\ln (\mathrm{FDI}) * \ln (\mathrm{IK} 2)$ & & & & $\begin{array}{l}0.004 \\
(0.067)^{c}\end{array}$ & \\
\hline $\ln (\mathrm{FDI}) * \ln (\mathrm{IK} 3)$ & & & & & $0.004(0.179)$ \\
\hline Adj. $R^{2}$ & 0.989 & 0.989 & 0.989 & 0.989 & 0.989 \\
\hline SEE & 0.043 & 0.043 & 0.043 & 0.043 & 0.043 \\
\hline $\begin{array}{l}\text { Sagan J- } \\
\text { statistic }\end{array}$ & $\begin{array}{l}1.322 \\
(0.724)\end{array}$ & $\begin{array}{l}1.330 \\
(0.722)\end{array}$ & $\begin{array}{l}1.198 \\
(0.753)\end{array}$ & $\begin{array}{l}1.480 \\
(0.687)\end{array}$ & $1.486(0.686)$ \\
\hline
\end{tabular}

aSignificant at the $1 \%$ level of a two-tailed test

bSignificant at the $5 \%$ level of a two-tailed test

'Significant at the $10 \%$ level of a two-tailed test

Column 2 contains the results from re-estimating the base model while including the interaction between FDI and our index of the size of the aggregate stock of transportation, power-generating, and telecommunication capitals. Compared to the signs and significance from the base model, the main difference is the low level (10\%) of statistical significance of the estimated coefficient on FDI if a twotailed test is used, or $0.077 / 2=3.85 \%$ level under a one-tailed test. The parameter estimate associated with the interaction term involving FDI and aggregate infrastructure capital, $P C I K$, is positive and statistically significant at the $1 \%$ level. Thus it appears that the growth effect of FDI is enhanced by the size of the host country's stock of infrastructure capital.

The model in column 3 replaces the index of aggregate infrastructure capital stock with the size of the transportation infrastructure (IK1). This modification does not markedly affect the signs and significance of the coefficients on the primary regressors but makes the estimated coefficient on the interaction terms statistically insignificant.

The interaction between power-generating infrastructure and FDI is modeled in column 4 of Table 1 where the estimated coefficient International Advances in Economic Research, Vol 20, No. 2 (May 2014): pg. 203-212. DOI. This article is @ International Atlantic Economic Society and permission has been granted for this version to appear in e-Publications@Marquette. International Atlantic Economic Society does not grant permission for this article to be further copied/distributed or hosted elsewhere without the express permission from International Atlantic Economic Society. 
on this variable is statistically significant at the $10 \%$ level of a twotailed test ( or $0.067 / 2=3.35 \%$ level of a one-tailed test). Note that the parameter estimates associated with all other regessors of the model in column 4 have the expected signs and are significant at reasonable levels of siginificance.

The third and final infrastructure capital to consider is that of telecommunication, $I K 3$. The estimation results in column 5 indicate that the direct effect of FDI is negative but is not statistically significant at conventional levels. On the other hand, the estimated coefficient on the interaction term is positive but it, too, is not statistically significant under a two-tailed test although it is significant at the $10 \%$ level of a one-tailed test. We conclude our discussion of the results in Table 1 by noting that in none of the five estimated equations is the Sargan J-statistic significant thus validating the instruments used in GMM estimation.

\section{Summary and Suggestions for Further Research}

In this paper we postulated that the effect of FDI on real income per capita may depend, at least in part, on the degree to which the economy's infrastructure base is developed. We tested this hypothesis using a panel of 46 countries and 5-year averages covering the 19802000 period along with measures of the size of transportation, powergenerating, and telecommunication infrastructures.

Our findings indicate that in general the overall infrastructure base of the host country in terms of all three types of infrastructure capital help to improve the marginal effect of FDI on real income. However, individually, only power-generating capital appears to make a statistically positive contribution to the growth effect of FDI, albeit at a relatively low level of confidence.

The research reported in this paper can be improved and extended in several ways. Throughout the paper we referred to the collection of transportation, power-generation, and telecommunication capacity of a country as its infrastructure base. But this is too narrow of a definition as many other forms of public and quasi-public capital such as police stations, school houses, fire stations, sewage systems, water treatment plants, waterways, etc. also constitute a country's 
infrastructure. It would be interesting to see whether our findings hold for other types of infrastructure capital, recognizing that data availability issues make this a challenging task.

Another potentially valuable extension is to utilize an alternative econometric approach. Virtually all models of economic growth and development including ours are prone to the endogeneity/simultaneity problem as every right-hand-side variable is a potential source of endogeneity including human capital, saving rate, FDI, public capital, etc. We handled this problem using the GMM estimation method. Another approach is to specify a two-equation simultaneous-equations system in which both FDI and real income per capita are endogenous. Using specifications similar to those in Ang (2008) and Asiedu (2002), one equation would express FDI as a function of its determinants including infrastructure capital while the other would specify real income per capita as a function of FDI and other control variables. Using the results, one would estimate the proportion of the effect of FDI on real income that passes through the infrastructure base of the host economy.

\section{Appendix 1}

Table 2. Data sources

Per capita real GDP based on purchasing power parity World development indicators (PPP) in 2005 international dollars

Ratio of gross domestic saving to GDP

World Development Indicators

Growth rate of population over the age of 25 World Development Indicators

Years of secondary school completed by population age Barro and Lee (2000) 25 and older.

Stock of inward FDI as a percentage of GDP UN Conference on Trade and Development

Size of three types of infrastructure capital stock.

Calderón and Servén (2004).

\section{Appendix 2}

Table 3. Countries in the sample

$\begin{array}{ll}\text { Algeria } & \text { Indonesia } \\ \text { Australia } & \text { Israel } \\ \text { Austria } & \text { Italy } \\ \text { Bangladesh } & \text { Japan }\end{array}$

International Advances in Economic Research, Vol 20, No. 2 (May 2014): pg. 203-212. DOI. This article is @ International Atlantic Economic Society and permission has been granted for this version to appear in e-Publications@Marquette. International Atlantic Economic Society does not grant permission for this article to be further copied/distributed or hosted elsewhere without the express permission from International Atlantic Economic Society. 
NOT THE PUBLISHED VERSION; this is the author's final, peer-reviewed manuscript. The published version may be accessed by following the link in the citation at the bottom of the page.

$\begin{array}{ll}\text { Belgium } & \text { Kenya } \\ \text { Bolivia } & \text { Malaysia } \\ \text { Brazil } & \text { Mexico } \\ \text { Canada } & \text { Netherlands } \\ \text { Chile } & \text { New Zealand } \\ \text { China } & \text { Nicaragua } \\ \text { Colombia } & \text { Norway } \\ \text { Costa Rica } & \text { Panama } \\ \text { Denmark } & \text { Philippines } \\ \text { Ecuador } & \text { Portugal } \\ \text { El Salvador } & \text { Senegal } \\ \text { Finland } & \text { South Africa } \\ \text { France } & \text { Spain } \\ \text { Ghana } & \text { Sweden } \\ \text { Greece } & \text { Thailand } \\ \text { Guatemala } & \text { United Kingdom } \\ \text { Honduras } & \text { United States } \\ \text { Iceland } & \text { Uruguay } \\ \text { India } & \text { Venezuela }\end{array}$

\section{References}

Aitken, B., \& Harrison, A. E. (1989). Do domestic firms benefit from foreign investment? Evidence from Venezuela. American Economic Review, 89, 605-618.

Alfaro, L., Chanda, A., Kalemli-Ozcan, S., \& Sayek, S. (2004). FDI and economic growth: the role of local financial markets. Journal of International Economics, 64, 89-112. (2006). How does foreign direct investment promote economic growth? Exploring the effects of financial markets on linkages. Harvard Business School Working Paper.

Ang, J. B. (2008). Determinants of foreign direct investment in Malaysia. Journal of Policy Modeling, 30, 185-189.

Asiedu, E. (2002). On the determinants of foreign direct investment to developing countries: is Africa different? World Development, 30, 107-119.

Bairam, E., \& Ward, B. (1993). The externality effect of government expenditure on investment in OECD countries. Applied Economics, 25, 711-716. 
Balasubramanyam, V. M., Salisu, M., \& Sapsford, D. (1996). Foreign direct investment and growth in EP and IS countries. The Economic Journal, 92, 105.

Barro, R.J., \& Lee, J-W. (2000). "International data on educational attainment: Updates and implications" (Center for International Development Working Paper No. 42).

Bengoa-Calvo, M., \& Sanchez-Robels, B. (2003). "Foreign direct investment as a source of endogenous growth". Universidad de Cantabria, Economics Working Paper No. 5/03.

Blomstrom, M., Zejan, M., \& Lipsey, R. E. (1992). "What explains developing country growth?" National Bureau of Economic research working paper no. 4132.

Borensztein, E., De Gregorio, J, \& Lee, J. (1998). "How does foreign direct investment affect economic growth?" National Bureau of Economic Research, Working Paper No. 5057.

Buiter, W. H. (1977). Crowding out and the effectiveness of fiscal policy. Journal of Public Economics, 7, 309-328.

Calderón, C., \& Servén, L. (2004). "The effects of infrastructure development on growth and income distribution". World Bank Policy research working paper no. 3400.

Choong, C., Yusop, Z., \& Soo, S. (2004). Foreign direct investment, economic growth, and financial sector development: a comparative analysis. ASEAN Economic Bulletin, 21(278), 289.

Ciruelos, A., \& Wang, M. (2005). International technology diffusion: effects of trade and FDI. Atlantic Economic Journal, 33, 437449.

Damijan, J.P., Knell, M., Majcen, B., \& Rojec, M. (2003). "Technology transfer in FDI in Top-10 transition countries: How important are direct effects, horizontal and vertical spillovers." William Davidson Working Paper, University of Michigan, No. 549.

Deichmann, J., Karidisy, S., \& Sayek, S. (2003). Foreign direct investment in Turkey: regional determinants. Applied Economics, 35, 1767-1778.

Dutta, N., \& Roy, S. (2008). "Foreign direct investment, financial development and political risks". MPRA Working Paper No. 10186.

Eberts, R.W. (1986). "Estimating the contribution of urban public infrastructure to regional economic growth". Working paper no. 8610, Federal Reserve Bank of Cleveland. 
Figlio, D., \& Blonigen, B. (2000). The effects of foreign direct investment on local communities. Journal of Urban Economics, $48,338-363$.

Grossman, G., \& Helpmann, E. (1991). Innovation and growth in the global economy. Cambridge: MIT Press.

Grossman, P. J. (1988). Growth in government and economic growth: the Australian experience. Australian Economic Papers, 27, 3344.

Hermes, N., \& Lensink, R. (2003). Foreign direct investment, financial development and economic growth. The Journal of Development Studies, 40, 142-163.

Kirkpatrick, C., Parker, D., \& Zhang, Y. (2006). Foreign direct investment in infrastructure in developing countries: does regulation make a difference? Transnational Corporations, 15, 144-171.

Kohpaiboon, A. (2002). "Foreign trade regime and FDI-growth nexus: a case study of Thailand". Australian National University Working Paper No. 2002-2005.

Krogstrup, S., \& Matar, L. (2005). "Foreign direct investment, absorptive capacity, and growth in the Arab World". HEI Working Paper No. 02/2005.

Kumar, N. (1994). Determinants of export orientation of foreign production by U.S. multinationals" an inter-country analysis. Journal of International Business Studies, 25, 141-156.

Lipsey, R.E. (2002). "Home and host country effects of FDI", NBER Working Paper No. W9293.

Mankiw, N. G., Romer, D., \& Weil, D. N. (1992). A contribution to the empirics of economic growth. The Quarterly Journal of Economics, 107, 407-437.

Maswana, J.-C. (2008). China's financial development and economic growth: exploring the contradictions. International Research Journal of Finance and Economics, 19, 89-99.

Nourzad, F. (2008). Openness and the efficiency of FDI: a panel stochastic production frontier study. International Advances in Economic Research, 14, 25-35.

Ram, R. (1986). Government size and economic growth: a new framework and some evidence from cross-section and time series data. American Economic Review, 76, 191-203. 
Romer, P. (1986). Increasing returns and long run growth. Journal of Political Economy, 94, 102-137.

Romer, P. (1987). Growth based on increasing returns due to specialization. American Economic Review, 77, 56-62.

Turnovsky, S. J. (1996). Fiscal policy, adjustment costs, and endogenous growth. Oxford Economic Papers, 48, 361-381.

Urata, S., \& Kawai, H. (2000). "Intrafirm technology transfer by Japanese Manufacturing Firms in Asia". The role of foreign direct investment in East Asian economic development. Chicago: University of Chicago Press.

Wheeler, D., \& Mody, A. (1992). International investment location decisions: the case of US firms. Journal of International Economics, 33, 57-76.

$\mathrm{Xu}, \mathrm{B}$. (2000). Multinational enterprises, technology diffusion, and host country productivity growth. Journal of Development Economics, 62, 477-493.

Yamin, M., \& Sinkovics, R. (2009). Infrastructure or foreign direct investment? An examination of the implications of MNE strategy for economic development. Journal of World Business, 44, 144157.

Zhuang, H. (2011). Foreign direct investment and public highway expenditures: evidence from the United States. Review of Business Research, 11, 189-194.

International Advances in Economic Research, Vol 20, No. 2 (May 2014): pg. 203-212. DOI. This article is (C International Atlantic Economic Society and permission has been granted for this version to appear in e-Publications@Marquette. International Atlantic Economic Society does not grant permission for this article to be further copied/distributed or hosted elsewhere without the express permission from International Atlantic Economic Society. 